\title{
Haematological and biochemical profile of Friesian $x$ Bunaji heifers supplemented with inorganic selenium and vitamin $\mathbf{E}$ \\ ${ }^{*}$ Achi, N. P., ${ }^{1}$ Barje, P. P., ${ }^{2}$ Abdulrashid, M., ${ }^{2}$ Daudu, O. M. and ${ }^{2}$ Achi, J. N. ${ }^{\prime}$ Dairy Research Programme, National Animal Production Research \\ Institute/Ahmadu Bello University, Shika-Zaria. \\ ${ }^{2}$ Department of Animal Science, Ahmadu Bello University, Zaria. \\ Abstract *Corresponding author: neyuachi@gmail.com.+2348065611639
}

A study was conducted using twenty Friesian $x$ Bunaji heifers to evaluate the effect of supplementing inorganic feed grade Selenium and Vitamin $E$ on the haematological and biochemical profile. The study consists of four treatments with five animals per Treatment in a Completely Randomized Design (CRD). Treatment 1 served as Control without Selenium or Vitamin E supplementation. Treatment 2 was supplemented with $3 \mathrm{mg}$ of feed grade Selenium. Treatment 3 with $20 \mathrm{mg}$ offeed grade Vitamin E. Treatment 4 had a combination of $3 \mathrm{mg}$ feed grade Selenium and $20 \mathrm{mg}$ of Vitamin E. Two sets of blood samples were taken from the animal via jugular venipuncture using a $10 \mathrm{~mL}$ syringe fitted with a needle into sample bottles for haematological and biochemical analysis. Neutrophils (19.78 - 29.88\%) were similar $(p<0.05)$ and Se supplementation recording the highest value. Packed cell volume (19.14-22.22\%), Haemoglobin, Red blood cells, White blood cells, Eosinophil, Monocytes, Basophil and Lymphocytes analyzed were similar ( $p>0.05)$. It was observed that there were similarities ( $p>0.05)$ in Glucose, Serum protein, globulin, urea N, albumin, MDA protein, AST, ALT and ALP analyzed except for GSH-Px $(22.38-24.70 \mu / \mathrm{ml})$. Glutathione peroxidase was higher $(p<0.05)$ in Friesian $x$ Bunaji heifers supplemented with vitamin $E$ and lowest with no supplementation. All parameters analyzed were within the normal range for apparently healthy cattle thereby suggesting that Selenium and Vitamin E as antioxidant are effective in scavenging for free radicals and reducing oxidative damage.

Keywords; Haematology, Biochemical, Selenium, Vitamin E, Friesian x Bunaji

\section{Introduction}

During the last 10 years, understanding of the importance of selenium and vitamin $\mathrm{E}$ for dairy cattle has increased tremendously. Scientific experiments have established that vitamin E and Selenium (Se) can influence the function of certain immune cells, reduce calf mortality and morbidity, and improve reproductive and mammary gland health in adult dairy cows. Vitamin E functions as an intra-cellular antioxidant scavenging for free reactive oxygen and lipid hydroperoxidases, and converting them to non-reactive forms, thus maintaining the integrity of membrane phospholipids against oxidative damage and peroxidation (Sinclair et al., 2000). The health of the cows can be evaluated and depends on haematologic and biochemical profile of blood. Haematology is highly informative as a diagnostic tool in bovine medicine, not solely, but in combination with clinical examination or other diagnostic procedures (Roland et al., 2014). Testing of physiological parameters is essential to monitoring the health status of dairy herds. The most popular blood diagnostic test is the blood count determination, which includes erythrocyte, leukocyte and thrombocyte counts, as well as hemoglobin content, hematocrit value and red blood cell parameters. The content of blood components varies depending on factors that inhibit or stimulate the circulatory system. The main function of blood is to maintain the body's 


\section{Haematological and biochemical profile of Friesian $x$ Bunaji heifers}

physiological balance, while the haematological blood indicators are the main determinant of the animals' environmental adaptation and thus their welfare (Anderson et al., 1999, Sattar and Mirza, 2009). Biochemical tests evaluate the body's internal condition, the function of different organs (including kidneys and the liver) and the course of metabolic changes in the body (Scamell, 2006). Vitamins and minerals perform vital roles in the growth and reproductive health of animals. Therefore, the objective of this study was to evaluate the effect of supplementing inorganic feed grade selenium and vitamin $\mathrm{E}$ on haemetological and biochemical profile of Friesian $\mathrm{x}$ Bunaji heifers.

\section{Materials and methods \\ Studylocation}

The studies were conducted at the Dairy Research Programme Farm of the National Animal Production Research Institute (NAPRI), Ahmadu Bello University, Shika-Zaria, Nigeria. Shika is located in the Northern Guinea Savanna and lies on latitudes $11^{\circ} 06^{\prime} 40^{\prime \prime} \mathrm{N}$ and longitudes $7^{\circ} 43$ 21 'E at an elevation of $644 \mathrm{~m}$ above sea level, with an annual maximum and minimum temperature of $31.0 \pm 3.2{ }^{\circ} \mathrm{C}$ and $18.0 \pm 3.7{ }^{\circ} \mathrm{C}$, respectively. Shika has an average annual rainfall of $1100 \mathrm{~mm}$, usually lasting from May to October with a mean relative humidity of $72 \%$. The dry season lasts from November to April with the mean daily temperature, ranging from $15-36{ }^{\circ} \mathrm{C}$ and mean relative humidity ranging from 20-37\% (IAR, 2017).

Experimental design and management of animals

A total of twenty Friesian x Bunaji heifers animals were used for the study. The study consists of four Treatments with five animals per Treatment in a Completely Randomized Design (CRD). Treatment I served as Control without Selenium or Vitamin E supplementation. Treatment II was supplemented with $3 \mathrm{mg}$ of feed grade Selenium. Treatment III with $20 \mathrm{mg}$ of feed grade Vitamin E. Treatment IV received a combination of $3 \mathrm{mg}$ feed grade Selenium and $20 \mathrm{mg}$ of Vitamin E. The animals were grazed on free range pastures and supplemented a concentrate diet consisting of $48 \%$ Cotton Seed Cake, $13.7 \%$ wheat bran, $35.3 \%$ maize, $2 \%$ bone meal, $1 \%$ common salt, $88 \%$ dry matter, $15 \%$ crude protein and $55 \%$ total digestible nutrients after grazing. Water was provided adlibitum. All the experimental animals were ear-tagged for identification. The animals were dipped once a week during the dry season and twice a week during the wet season for effective control of ectoparasites. Twenty Friesian $\mathrm{x}$ Bunaji heifers weighing between $150-200 \mathrm{~kg}$ were used for this study; the animals were allotted to four treatments with five animals per treatment. The four Treatments included: Treatment 1 served as the Control without supplementation of either Selenium or Vitamin E. Treatment 2 was supplemented with $3 \mathrm{mg}$ of feed grade Selenium. Treatment 3 was administered $20 \mathrm{mg}$ of feed grade Vitamin E. Treatment 4 received a combination of $3 \mathrm{mg}$ feed grade Selenium and $20 \mathrm{mg}$ of Vitamin E. All the experimental animals were on the four Treatments for a period of 120 days, which were supplemented on weekly interval.

\section{Blood sample collection}

Two sets of blood samples were taken from the animal via jugular venipuncture using a $10 \mathrm{~mL}$ syringe fitted with a needle. Ten $\mathrm{mL}$ blood samples collected were put in the heparin free bottles as anticoagulant for the determination of haematological parameters. Blood samples for serum analysis were collected into EDTA free bottles and allowed to coagulate at room temperature. The supernatant sera were then 


\section{Achi, Barje, Abdulrashid, Daudu and Achi}

harvested and stored in a freezer for subsequent biochemical analysis.

\section{Chemical analysis}

Packed cell volume (PCV) and haemoglobin $(\mathrm{Hb})$ concentration was determined following the Procedures outlined by Dacie and Lewis (2001). Red blood cells (RBC) and total white blood cells (WBC) were also determined as described by Jain, (1986). Serum total protein, serum urea $\mathrm{N}$, globulin and creatinine was determined using the Method described by Ogunsami et al. (2002). The activity of the alanine transaminase (ALT), aspartate transaminase (AST) and alkaline phosphate ( A L P) was analyzed using spectrophotometric linked reaction method (Cheesbrough, 2004). Glutathione peroxidase (GSH-Px), Se and Vitamin E was analyzed according to the procedure described by Ursini et al. (1985).

\section{Statistical analysis}

Data were analyzed using the General Linear Model of SAS (2002). Significant means were compared using Dunnett (1964).

\section{Results and discussion}

Table 1 shows the results of haematological parameters of Friesian x Bunaji heifers. Neutrophils (19.78 - 29.88\%) were similar $(\mathrm{p}<0.05)$ and Se supplementation recording the highest value. Packed cell volume (19.14 - 22.22\%), Haemoglobin (8.60 $19.12 \mathrm{~g} / \mathrm{dl})$, Red blood cells $(4.46-5.36$ $\left.\mathrm{x} 10^{12} / 1\right)$, White blood cells $(9.80-0.46$ $\left.\mathrm{x} 10^{9} / 1\right)$, Eosinophil (6.52 - 8.20\%), Monocytes (1.72 - 2.78\%), Basophil (0.76 - $1.00 \%)$ and Lymphocytes (60.12 $67.72 \%)$ analyzed were similar ( $\mathrm{p}>0.05)$. Vitamins and minerals as antioxidants play an important role in the growth and reproductive performance of animals. Antioxidants have been defined as any substances that delay or inhibit oxidative damage to cellular molecule (Gutteridge et al., 1994). Vitamin E and Selenium are essential nutrients that have complementary biological functions as antioxidants to minimize cellular damage caused by endogenous peroxides (Kolb et al., 1997). Vitamin $\mathrm{E}$ and selenium are involved in related functions; therefore, a selenium deficiency could be partially compensated by an adequate intake of vitamin $\mathrm{E}$ and vice versa. There is a close link between selenium and vitamin $\mathrm{E}$ status and antioxidant status (Chauhan, 2014). The parameters measured in the present study were not significantly different $(p>0.05)$ except for neutrophils that was significantly different. All parameters however were within the normal range for apparently healthy cattle. The insignificant difference in most of the parameters observed in this study could be as a result of the relatively adaptive mechanism of the animals and an indication of their apparently healthy status. The significant difference $(p<0.05)$ observed with the neutrophills values in this study could be as a result of the favourable response of neutrophils activity, T-cell function, macrophage activity and antibody production with vitamin $\mathrm{E}$ supplementation (Politis et al., 1995; Politis et al., 1996; Reddy et al., 1986). Selenium has a biological function related to vitamin $\mathrm{E}$ in that $\mathrm{Se}$ is an indispensable constituent of glutathione peroxidase, an enzyme involved in detoxifation of hydrogen peroxide and lipid hydro peroxides. Moreover, $\mathrm{Se}$ is a component of selenoproteins and is involved in immune and neuropsychological function in the nutrition of animals (Meschy, 2000) which agrees with the findings of this study. Vitamin E prevents oxidative damage to sensitive membrane lipids by suppressing hydro peroxide formation (Chow, 2001) and protects cellular membranes thus maintaining membrane integrity and reducing oxidative stress (Hogan et al., 1993). 


\section{Haematological and biochemical profile of Friesian $x$ Bunaji heifers}

Table 1: Effect of Selenium, Vitamin E and Selenium + Vitamin E on hematological parameters of Friesian x Bunaji heifers

\begin{tabular}{lllllll}
\hline Parameters & Control & Se & Vit-E & Se + Vit-E & SEM & P-value \\
& & & & & & \\
\hline Packed Cell Volume (\%) & 22.22 & 20.86 & 20.78 & 19.14 & 1.49 & 0.5552 \\
Haemoglobin (g/dl) & 8.98 & 9.46 & 8.60 & 19.12 & 0.42 & 0.5526 \\
Red Blood Cell (x10 $12 / 1)$ & 5.36 & 5.14 & 5.01 & 4.46 & 0.39 & 0.4586 \\
White Blood Cell (x & 12.46 & 10.78 & 9.80 & 11.44 & 1.02 & 0.3372 \\
10 $/ 1$ ) & & & & & \\
Eosinophil (\%) & 8.18 & 8.20 & 6.92 & 6.52 & 0.79 & 0.3514 \\
Monocytes (\%) & 2.50 & 1.72 & 1.74 & 2.78 & 0.46 & 0.2878 \\
Basophil (\%) & 0.70 & 1.00 & 0.76 & 0.70 & 0.16 & 0.5337 \\
Lymphocytes (\%) & 64.06 & 67.72 & 64.94 & 60.12 & 2.70 & 0.2928 \\
Neutrophils (\%) & $25.14^{\text {ab }}$ & $19.78^{\text {a }}$ & $24.14^{\text {ab }}$ & $29.88^{\mathrm{b}}$ & 1.61 & 0.0041 \\
${ }^{\text {ab Means within the same row having different superscript are significantly (P>0.05) different. Se-Selenium, Vit-E-Vitamin E }}$
\end{tabular}

Table 2 shows the effect of Se, vitamin E and $\mathrm{Se}+$ vitamin $\mathrm{E}$ on biochemical parameters of Friesian x Bunaji heifers. It was observed that there were similarities $(p>0.05)$ in Glucose, Serum protein, globulin, urea N, albumin, MDA protein, AST, ALT and ALP analyzed except for GSH-Px. Glutathione peroxidase (22.38 $24.70 \mu / \mathrm{ml})$ was higher $(\mathrm{p}<0.05)$ in Friesian $\mathrm{x}$ Bunaji heifers supplemented with vitamin E and lowest with no supplementation. The gluthathione peroxidase (22.38 $24.70 \mu / \mathrm{ml}$ ) obtained for Friesian x Bunaji heifers supplemented with Se, vitamin E and $\mathrm{Se}+$ vitamin $\mathrm{E}$ was within the normal range for apparently healthy cattle (Radkowska and Herbut, 2014). The increase in the GSH-Px values observed in the present study could be attributed to the positive relationship between Se and GSHPx activity in the blood. Chorfi et al. (2011) reported that Se supplementation in the diets of heifers increased Se content and GSH-Px content in the blood. The increase would have been more pronounced if organic forms of Se was used compared to the inorganic form used in this study (Ran et al., 2010; Chorfi et al., 2011). The variation produced between organic and inorganic forms of Se has been found to be about $20 \%$ for blood Se content and 16\% for GSH-Px activity as reported by Weiss and Hogan (2005) although the inorganic form of Se was used for this study. The liver function enzymes observed in the present study had values within the normal ranges for apparently healthy animals (Radkowska and Herbut, 2014) thereby depicting there was neither deficiency nor toxicity. Selenium is bound to $\alpha$ and $\beta$-globulins, LDL (low density lipoprotein) and VLDL (very low density lipoprotein) and albumin (Schrauzer et al., 2000). The albumin content observed in this study was within normal range in the blood of cattle as reported by (Dargatz et al., 1996).

The variation produced between organic and inorganic forms of Se has been found to be about $20 \%$ for blood Se content and $16 \%$ for GSH-Px activity (Weiss and Hogan, 2005). The liver function enzymes observed in the present study revealed that the values were within the normal ranges for apparently healthy animals thereby depicting there was neither deficiency nor toxicity. 
Achi, Barje, Abdulrashid, Daudu and Achi

Table 2: Effect of Selenium, Vitamin E and Selenium + Vitamin E on biochemical parameters of Friesian x Bunaji heifers

\begin{tabular}{|c|c|c|c|c|c|c|}
\hline Parameters & Control & $\mathrm{Se}$ & Vit-E & $\mathrm{Se}+$ Vit-E & SEM & P-value \\
\hline Glucose $(\mathrm{g} / \mathrm{dL})$ & 46.20 & 43.02 & 49.38 & 51.40 & 2.74 & 0.1877 \\
\hline Total Protein $(\mathrm{g} / \mathrm{dL})$ & 5.32 & 5.40 & 5.22 & 5.76 & 0.23 & 0.3848 \\
\hline Globulin (g/dL) & 3.28 & 3.4 & 3.02 & 3.44 & 0.24 & 0.6516 \\
\hline Urea N (mg/dL) & 3.06 & 3.58 & 3.84 & 3.8 & 0.23 & 0.1416 \\
\hline $\operatorname{Albumin}(\mathrm{g} / \mathrm{dL})$ & 2.34 & 2.52 & 2.28 & 2.48 & 0.13 & 0.5262 \\
\hline Creatine (mg/dL) & 1.34 & 1.26 & 1.06 & 1.30 & 0.09 & 0.1969 \\
\hline $\begin{array}{l}\text { MDA Protein } \\
\text { (Mmols/mg) }\end{array}$ & 11.98 & 12.22 & 11.84 & 11.98 & 0.27 & 0.8068 \\
\hline $\mathrm{SOD}(\mathrm{u} / \mathrm{ml})$ & 44.62 & 43.94 & 42.82 & 40.80 & 2.74 & 0.7758 \\
\hline $\mathrm{AST}(\mathrm{IU} / \mathrm{L})$ & 38.20 & 45.00 & 43.60 & 43.20 & 4.13 & 0.6772 \\
\hline ALT (IU/L) & 15.80 & 16.40 & 15.00 & 16.20 & 1.10 & 0.8130 \\
\hline $\operatorname{ALP}(\mathrm{IU} / \mathrm{L})$ & 38.60 & 40.00 & 39.80 & 39.40 & 2.37 & 0.9762 \\
\hline GSH-Px $(\mu / \mathrm{ml})$ & $22.38^{\mathrm{b}}$ & $24.24^{\mathrm{ab}}$ & $24.70^{\mathrm{a}}$ & $23.62^{\mathrm{ab}}$ & 0.55 & 0.0479 \\
\hline
\end{tabular}

\section{Conclusions}

It can be concluded that the haematological and biochemical profile of Friesian $\mathrm{x}$ Bunaji heifers were within the normal reference point suggesting that the animals were apparently healthy. It therefore affirmed that Selenium and Vitamin E has an important role to play in scavenging for free radicals and reducing oxidative stress.

\section{References}

Anderson, B. H., Watson, D. L. and Colditz, I. G. 1999. The effect of dexamethasone on some immunological parameters in cattle. Veterinary Research Communication 23, 399-413.

Chorfi, Y., Girard, V., Fournier, A. and Couture, Y. 2011. Effect of subcutaneous selenium injection and supplementary selenium source on blood selenium and glutathione peroxidase in feedlot heifers. Canadian Veterinary Journal. 52, 1089-1094.

Chow, C. K. 2001. In: R. Rucker, D.B. Suttle, McComick, L. Machlin and J. Editors, 2001. Handbook of vitamins. Marceldekker, New
York, pp: 165-196

Dunnett, C. W. 1964. "New tables for multiple comparisons with a control", Biometrics, 20: 482-491

Dacie, J. V. and Lewis, S. M. 2001. Practical Heamatology $9^{\text {th }}$ ed. Churchill Livingstone, London, $\mathrm{p}$. 633.

Dargatz, D. A. and Ross, P. F. 1996. Blood selenium concentrations in cows and heifers on 253 cow-calf operations in 18 states. Journal Animal Science. 74, 2891-2895.

Jain, N. C. 1986. Schalm Veterinary Haematology. 4th ed. Lea and Febiger, Philadelphia, USA.

Gutteridge, J. M. C. and Halliwell, B. C. 1994. Free radicals and antioxidants in ageing and disease: Fact or Fantasy. In: Antioxidants in nutrition, Health and Disease. Oxford University Press. Oxford, pp: 111-123.

Hogan, J. S., Weiss, W. P. and Smith, K. L. 1993. Role of vitamin $E$ and Selenium in host defense against mastitis. Journal of Dairy Science.76: 2795-2803.

Kolb, E., KasKousb, S. and Scchawer, J. 


\section{Haematological and biochemical profile of Friesian $x$ Bunaji heifers}

1997. Nutrional aspects of the importance, utilization, metabolism and the use of vitamin $\mathrm{E}$ and selenium in sheep. Berliner und Munchener Tierarztliche Wochenschrift, 110: 178-184.

Meschy, F. 2000. Recent progress in the assessment of mineral requirements of goats. Livestock Production Science, 64: 9-14.

Ogunsanmi, O.A., Ozegbe, P.C., Ogunjobi, D., Taiwo, V.O. and Adu, J.O. 2002. Haematology plasma Biochemistry and whole blood minerals of the captive Adult African Grasscutter (Thryonomys swinderiamus, Temnick) Tropical Veterinary Medicine, 20(1): 27-35.

Reddy, P. G., Morrill, J. L., Minocha, H. C., Morrill, M. B., Dayton, A. D., Frey, R. A. 1986. Effect of supplemental vitamin $\mathrm{E}$ on the immune system of calves. Journal of Dairy Science. 69: 164-171.

Politis, I., Hidiroglou, M., White, J. H., Gilmore, J. A., Williams, S. N., Scherf, H., Frigg, M. 1996. Effects of vitamin E on mammary and blood leukocyte function, with emphasis on chemotaxis, in periparturient dairy cows. American Journal of Veterinary Research, 57: 468-471

Politis, I., M. Hidiroglou, T. R. Batra, J. A. Gilmore, R. C. Gorewit, and H. Scherf. 1995. Effects of vitamin $\mathrm{E}$ on immune function of dairy cows. American Journal of Veterinary Research. 56:179-184.

Radkowska, I. and Herbut, E. 2014. Hematological and biochemical blood parameters in dairy cows depending on the management system. Animal Science Papers and Reports vol. 32 (4), 317-325.
Roland, L., Drillich, M. and Iwersen, M. 2014. Hematology as a diagnostic tool in bovine medicine. Journal of Veterinary Diagnostic Investigation Vol. 26(5):592-598.

Ran, L., Wu, X., Shen, X., Zhang, K., Ren, F. and Huang, K. 2010. Effects of selenium form on blood and milk selenium concentrations, milk component and milk fatty acid composition in dairy cows. Journal of Science, Food and Agriculture, 90, 2214-2219.

Sattar A. and Mirza R. H. 2009. Hematological parameters in exotic cows during gestation and lactation under subtropical conditions. Pakistan Veterinary Journal 29, 129-132.

SAS. 2002. User's Guide Version 8.1. Statistical Analysis System Institute Inc, Cary, Nc, USA.

Scamell, J. M. 2006. Healthy land for healthy cattle. Cattle Practice 14, 143-152.

Schrauzer, G. N. 2000. Selenomethionine: A review of its nutritional significance, metabolism and toxicity. Journal of Nutrition, 130, 1653-1656.

Sinclair, K. D., Kuran, M., Gebbie, F.E., Webb, R, and McEvoy, T.G. 2000. Nitrogen metabolism and fertility in cattle: Development of oocytes recovered from heifers offered diets differing in their rate of nitrogen release in the rumen, Journal of Animal Science, 78, pp 2670-2680.

Ursini, F., Maiorino, M. and Gregolin, C. 1985. The selenoenzyme phospholipid hydroperoxide glutathione peroxidase. Biochimica et Biophysica Acta 839, $62-70$.

Weiss, W. P. and Hogan, J. S. 2005. Effect 
of selenium source on selenium status, neutrophil function, and response to intramammary endotoxin challenge of dairy cows. Journal of Dairy Science. $88,4366-4374$.

Received: $19^{\text {th }}$ September, 2018

Accepted: $21^{\text {st }}$ December, 2018 